\title{
Oil-lipids, carotenoids and fatty acids simultaneous production by Rhodotorula mucilaginosa CCT3892 using sugarcane molasses as carbon source
}

\author{
Produção simultânea de óleos-lipídeos, carotenoides e ácidos \\ graxos por Rhodotorula mucilaginosa CCT3892 utilizando \\ melaço de cana-de-açúcar como fonte de carbono \\ Willyan Araújo da Costa ${ }^{1 *}$ (D), Carlos Eduardo de Araújo Padilha \\ Sérgio Dantas de Oliveira Júnior ${ }^{1}$, Flávio Luiz Honorato da Silva ${ }^{2}$, Josevan Silva ${ }^{2}$, \\ Maristela Alves Ancântara ${ }^{2}$, Márcio Ferrari ${ }^{3}$, Everaldo Silvino dos Santos ${ }^{3}$
}

\author{
${ }^{1}$ Universidade Federal do Rio Grande do Norte (UFRN), Centro de Tecnologia, Departamento de Engenharia \\ Química, Natal/RN - Brasil \\ ${ }^{2}$ Universidade Federal da Paraíba (UFPB), Centro de Tecnologia, Departamento de Engenharia de Alimentos, João \\ Pessoa/PB - Brasil \\ ${ }^{3}$ Universidade Federal do Rio Grande do Norte (UFRN), Centro de Saúde Petrópolis Natal, Natal/RN - Brasil
}

*Corresponding Author: Willyan Araújo da Costa, Universidade Federal do Rio Grande do Norte (UFRN), Campus Universitário, Av. Salgado Filho, 3000, Lagoa Nova, CEP: 58302-215, Natal/RN - Brasil,

e-mail: willyam.costaa@gmail.com

Cite as: Costa, W. A., Padilha, C. E. A., Oliveira Júnior, S. D., Silva, F. L. H., Silva, J., Ancântara, M. A., Ferrari, M. \& Santos, E. S. (2020). Oil-lipids, carotenoids and fatty acids simultaneous production by Rhodotorula mucilaginosa CCT3892 using sugarcane molasses as carbon source. Brazilian Journal of Food Technology, 23, e2019064. https://doi.org/10.1590/1981-6723.06419

\begin{abstract}
One of the most important classes of nutritional biomolecules is the oleaginous compounds group, which specially includes the oil-lipids, the carotenoids and the fatty acids. These biocompounds present a wide range of industrial applications because their ability to act as an energy source, antioxidants and metabolic agents for the human body. Therefore, the food industry, mainly focusing on food supplementation, is always searching for new sources of them. In this context, the present study evaluated the total lipids, carotenoids and fatty acids simultaneous production by the Rhodotorula mucilaginosa CCT3892 yeast, using residual sugarcane molasses as carbon source. The results obtained demonstrated that the cultivation of yeast in molasses medium (MC) produced the same content of total lipids and carotenoids ( $16.50 \% \pm 0.68 \%$ and $0.053 \pm 0.001 \mathrm{mg} \mathrm{g}^{-1}$, respectively) as the obtained from a synthetic medium (SC) $\left(15.36 \% \pm 1.36 \%\right.$ and $\left.0.051 \pm 0.001 \mathrm{mg} \mathrm{g}^{-1} 0.005\right)$. Concerning the fatty acids biosynthesis, the MC cultivation generated the most interesting profile once it presented a greater content of oleic acid (74.05\%), an unsaturated compound with high nutritional value. The cultivation carried out with the molasses and yeast extract supplementation (MYEC) did not provide an improvement in microbial oil production, what indicated that in this condition there was a predominance of others sorts of substrate metabolization by the yeast cells, as confirmed by the microbial kinetics study.
\end{abstract}

Keywords: Oil-lipids; Carotenoids; Fatty acids; Rhodotorula mucilaginosa; Sugarcane molasses; Simultaneous production. 


\section{Resumo}

Uma das mais importantes classes de moléculas nutricionais é a dos compostos oleaginosos, a qual inclui especialmente os óleos-lipídeos, os carotenoides e os ácidos graxos. Esses compostos apresentam um vasto campo de aplicações industriais pela habilidade de atuarem como fonte de energia para o corpo humano, antioxidantes e agentes metabólicos. Sendo assim, a indústria de alimentos, focando principalmente na suplementação de alimentos, está sempre procurando novas fontes deles. Nesse contexto, o presente estudo avaliou a produção simultânea de lipídeos totais, carotenoides e ácidos graxos pela levedura Rhodotorula mucilaginosa CCT3892, utilizando melaço de cana-de-açúcar como fonte de carbono. Os resultados obtidos mostraram que o cultivo da levedura em meio contendo melaço (MC) produziu o mesmo teor de lipídeos totais e carotenoides $(16,50 \% \pm 0,68 \%$ e $0,053 \pm 0,001 \mathrm{mg} \mathrm{g}^{-1}$, respectivamente) quando comparado com o produzido em meio sintéticos (SC) $\left(15,36 \% \pm 1,36 \%\right.$ e $0,051 \pm 0,001 \mathrm{mg} \mathrm{g}^{-1}$ 0,005). Sobre a síntese de ácidos graxos, o cultivo de MC gerou o perfil mais interessante, uma vez que este apresentou um conteúdo majoritário de ácido oleico (74,05\%), um composto insaturado com alto valor nutricional. O cultivo conduzido com melaço e suplementação de extrato de levedura (MYEC) não mostrou aumento na produção microbiana de óleos, o que indica que nessa condição prevaleceram outras formas de metabolização do substrato pelas células da levedura, como foi confirmado pelo estudo da cinética microbiana.

Palavras-chave: Óleos-lipídeos; Carotenoides; Ácidos graxos; Rhodotorula mucilaginosa; Melaço de cana-de-açúcar; Produção simultânea.

\section{Introduction}

One of the most important nutritional biomolecules categories for the food industry is the lipo-compounds group. These molecules are known by their insolubility in water and other polar solvents. In the nature, there are several examples of them such as the greases, the oils, some vitamins, hormones and the non-proteins compounds of the biological membranes (Voet \& Voet, 2013). From the biological point of view, the role played by the lipids is quite important since, besides their participation as energy source for biological systems, these biomolecules may act as enzymatic cofactors, electrons transporters, surfactants agents in the intestinal tract, intracell messengers, pigments and antioxidants.

Carotenoids and fatty acids are others examples of lipo-molecules with industrial value (Nelson \& Cox, 2014). Nowadays, there are a great number of products with these bio-substances in their compositions and some examples are: ice creams, vitamin complexes, industrial juices, candies and nutricosmetics (Mesquita et al., 2017).

In the industry, oil-lipids and carotenoids are obtained by extraction process using animal viscera or vegetables as raw materials. However, the extraction from vegetables is non-efficient due to the limitation associated with the climate dependence and soil specific requirements (Mata-Gómez et al., 2014). Moreover, the use of animals in industrial processes is not well seen by the new consumer profile, which is searching for products with no, or less, animal participation (Mouat \& Prince, 2018).

Related to this topic, other alternative is the chemical synthesis, which has been criticized for the reagents toxicity and the formation of undesired by-products (Cheng \& Yang, 2016).

Because of the problematic above mentioned, new researches are emerging and aiming to propose different pathways to obtain nutritional lipo-molecules. The bioprocesses using microbial cells as biocatalysts have been the most cited approach for this purpose (Garay et al., 2014).In this scenario, the yeasts from the Rhotodotorula species have appeared with high prominence due to their capacity to produce carotenoids, oil-lipids and an extensive fatty acids profile by the metabolization of alternative substrates (Kanzy et al., 2015; Ribeiro et al., 2017; Silva et al., 2018). 
Therefore, the objective of this study was to investigate the total lipids, carotenoids and fatty acids simultaneous production by the Rhodotorula mucilaginosa ССТ3892 yeast. Additionally, residual sugarcane molasses was also evaluated as an alternative carbon source.

\section{Material and methods}

\subsection{Sugarcane molasses}

The residual sugarcane molasses was supplied by Usina Japungu Agroindustrial, a sugar and ethanol plant situated in Santa Rita, State of Paraíba, Brazil (659'17’'S 3501'24’W). The hydrolysis of molasses sucrose content was performed according to Banzatto et al. (2013), what was done before using it in the bioprocess.

\subsection{Microorganism and maintenance}

The microorganism used was the Rhodotorula mucilaginosa CCT3892 yeast, supplied by André Tosselo Foundation - Tropical Cultures Collection (Campinas/Brazil). According to specifications given by the foundation, the yeast is classified as safe and no dangerous for humans or the environment (Biosafety level I). The strain was stored on Y. M. A. medium (Yeast Malt Agar), which consisted of $\left(\mathrm{g} \mathrm{L}^{-1}\right)$ : glucose (40.0), yeast extract (3.0), malt extract (3.0), peptone (5.0) and agar (20.0).

\subsection{Inoculum}

The inoculum was prepared by the addition of $5 \mathrm{~mL}$ of sterile distilled water on a glass plat containing the yeast culture. The suspension was readily transferred to a $500 \mathrm{~mL}$ Erlenmeyer flask containing $200 \mathrm{~mL}$ of the medium described in the item 2.4. Afterwards, the system was placed in an orbital shaker (New Brunswick Scientific $-\mathrm{C} 25 \mathrm{~K}$ ) at $30{ }^{\circ} \mathrm{C}$ and $200 \mathrm{rpm}$ for $24 \mathrm{~h}$. At last, $50 \mathrm{~mL}$ of the fermented liquid were centrifuged and the cell pellet formed was then resuspended in $5 \mathrm{~mL}$ of sterile distilled water. This last suspension was used to inoculate the bioprocesses. The initial inoculum concentration $\left(\sim 10^{7}\right.$ cells $\left.\mathrm{mL}^{-1}\right)$ was measured using a Neubauer chamber.

\subsection{Oil-compounds production by Rhodotorula mucilaginosa CCT3892}

In this study, in order to evaluate the lipids, carotenoids and fatty acids simultaneous production by Rhodotorula mucilaginosa ССТ389 in molasses, three processual conditions were formulated. The first was a synthetic medium (SC) as reported by Frengova et al. (1994), which was also used as a control and consisted of $\left(\mathrm{g} \mathrm{L}^{-1}\right)$ : glucose (40.0), $\mathrm{KH}_{2} \mathrm{PO}_{4}(8.0), \mathrm{MgSO}_{4} .7 \mathrm{H}_{2} \mathrm{O}(0.5)$ and yeast extract (3.0). The second condition (MC) was elaborated using only hydrolysate sugarcane molasses, diluted in a reducing sugar (RC) concentration of $40.0 \mathrm{~g} \mathrm{~L}^{-1}$. Finally, the third process, was carried out with molasses at the same RC content as MC, but supplemented with $3.0 \mathrm{~g} \mathrm{~L}^{-1}$ of yeast extract (MYEC). The experimental bioprocesses were realized in $250 \mathrm{~mL}$ Erlenmeyer flasks, containing $125 \mathrm{~mL}$ of each medium, for $120 \mathrm{~h}$ at $30^{\circ} \mathrm{C}$ and $200 \mathrm{rpm}$. All the cultivations were performed in triplicate. 


\subsection{Analytical methods}

\subsubsection{Sugarcane molasses characterization}

\subsubsection{1 $\mathrm{pH}$}

Sugarcane molasses $\mathrm{pH}$ was determined according to Zenebon et al. (2008). Triplicates of a molasses dilution in distilled water, 1:10 $\left(\mathrm{v} \mathrm{v}^{-1}\right)$, were prepared and their $\mathrm{pH}$ were measured using a $\mathrm{pH}$ meter (MS TECNOPON - LUCA 210).

\subsubsection{Total proteins}

The molasses total proteins quantification was realized in accordance with Bradford (1976). This methodology is based on the proteins and dyes affinity. The product obtained from this interaction has its absorbance $(595 \mathrm{~nm})$ recorded, using a spectrophotometer (ThermoSpectronic - GENESYS 10uv), and converted to proteins concentration ( $\mathrm{mg} \mathrm{L}^{-1}$ ), with the support of a standard curve constructed using Albumin (Sigma-Aldrich). The analysis was carried out in triplicate.

\subsubsection{Reducing sugars (glucose and fructose)}

The molasses glucose and fructose contents, before and after the hydrolysis treatment, were quantified by High Performance Liquid Chromatography (HPLC) using an ACELA platform (Thermo Scientific) coupled with a Shim-Pack column (Shimadzu Co., Japan). The operation temperature was $65^{\circ} \mathrm{C}$ and the mobile phase used was sulfuric acid $(5 \mathrm{mM})$ at a $0.6 \mathrm{~mL} \cdot \mathrm{min}^{-1}$ flow rate. The analysis was made in triplicate.

\subsubsection{Reducing sugars quantification}

To quantify the reducing sugars content in the sugarcane molasses, and its consumption along the bioprocesses, was used the 3,5-dinitrissalicilic method (Miller, 1959). The samples were all analyzed in triplicate.

\subsubsection{Dry cell concentration}

To measure the dry cell concentration, aliquots of $1 \mathrm{~mL}$ were taken from each replicate along the bioprocesses. Then, the samples were diluted in distilled water and their absorbances were recorded on a spectrophotometer (ThermoSpectronic - GENESYS 10uv) at $600 \mathrm{~nm}$. The absorbances were converted to dry cell concentration $\left(\mathrm{g} \mathrm{L}^{-1}\right)$ by a standard curve (Cardoso et al., 2016; Ribeiro et al., 2017). The analysis was also realized in triplicate.

\subsubsection{Total lipids extraction and quantification}

To extract and quantify the total lipids, Rhodotorula mucilaginosa dried cells obtained at $96 \mathrm{~h}$ of cultivation were treated according to Manirakiza et al. (2001). The results were expressed as lipids content per dry cell (\%). This quantification was realized in triplicate.

\subsubsection{Total carotenoids quantification}

The total intracellular carotenoids were quantified by resuspending in chloroform the oil obtained in item 2.5.3 and measuring its absorbance $(450 \mathrm{~nm})$ on a spectrophotometer (ThermoSpectronic - GENESYS 10uv). The absorbance was converted to total carotenoids concentration using Equation 1 (Kanzy et al., 2015; Cheng \& Yang, 2016). 


$$
[\text { Carotenoids }]_{\text {total }}=\frac{A \cdot V \cdot 10^{4}}{a \cdot m}
$$

In Equation 1, "[Carotenoids] total" is the total carotenoids concentration $\left(\mu \mathrm{g} \mathrm{g}_{\text {cell }}{ }^{-1}\right)$, " $\mathrm{A}$ " is the sample absorbance at $450 \mathrm{~nm}$, "V" is the solvent volume used to dissolve the oil-compounds, "a" is the carotenoids molar absorptivity (2592) and "m" is the cell mass used in the extraction.

\subsubsection{Fatty acids profile}

The oils obtained were transesterified according to IUPAC 2.301 (International Union of Pure and Applied Chemistry, 1987) standard method. Then, the samples were characterized on a Gas Chromatograph (CG), coupled with a mass detector (Shimadzu - GCMS-QP2010, Japan) and equipped with a Durabound DB-23 column $(30 \mathrm{~cm} \times 0.25 \mathrm{~mm} \times 0.25 \mu \mathrm{m})$. The operation temperature was $90{ }^{\circ} \mathrm{C}$ and helium was used as carrier gas at a $1,2 \mathrm{~mL} \cdot \mathrm{min}^{-1}$ flow rate.

\subsection{Stoichiometric parameters for the substrate conversion into yeast cells, lipids and carotenoids}

The stoichiometric parameters for the reducing sugars (S) conversion into microbial biomass, lipids and carotenoids were obtained according to Equations 2, 3 and 4, respectively.

$$
\begin{gathered}
Y_{X / S}=\frac{X_{f}-X_{0}}{S_{0}-S_{f}} \\
Y_{L / S}=\frac{L_{f}-L_{0}}{S_{0}-S_{f}} \\
Y_{C / S}=\frac{C_{f}-C_{0}}{S_{0}-S_{f}}
\end{gathered}
$$

The subscripts $(f)$ and $(0)$ denote the carotenoid concentration $(\mathrm{C})$, the lipid concentration $(\mathrm{L})$ or the cell concentration $(\mathrm{X})$ at the final and initial bioprocess period, respectively.

\subsection{Kinetics parameters}

The obtention of the cell productivity $\left(\mathrm{P}_{\mathrm{x}}\right)$, maximum specific growth rate $\left(\mu_{\max }\right)$ and the generation time $\left(\mathrm{T}_{\mathrm{g}}\right)$ was realized as expressed in Equations 5, 6 and 7 (Colet et al., 2015).

$$
\begin{aligned}
& P_{x}=\frac{\left(X-X_{0}\right)}{\Delta t} \\
& \ln (X)=\mu_{\max } \cdot \Delta t+\ln \left(X_{0}\right) \\
& T_{g}=\frac{\ln (2)}{\mu_{\max }}
\end{aligned}
$$

The terms $\mathrm{X}$ and $\mathrm{X}_{0}$ refer to final and initial cellular concentration and $\Delta \mathrm{t}$ is the time variation.

\subsection{Statistical analysis}

The statistical analysis was performed using the software EXCEL (Microsoft ${ }^{\circledR}$ ). Data were all compared and evaluated by the Tukey test at a 95\% confidence level. All data were shown as mean \pm standard deviation. 


\section{Results and discussions}

\subsection{Sugarcane molasses characterization}

The molasses characterization results (Table 1) confirm the residue application as alternative carbon source for microbial bioprocesses once it presented greater reducing sugars content. After the hydrolysis process, as expected, the glucose and fructose contents were increased and no growth inhibitors formation, such as hydroxymethylfurfural, was observed (Lima et al., 2013).

Table 1. Sugarcane molasses characterization.

\begin{tabular}{ccc}
\hline & Molasses & Molasses after inversion \\
\hline $\mathrm{pH}$ & 6.49 & $\mathrm{ND}$ \\
\hline Reducing sugars $\left(\mathrm{g} \mathrm{L}^{-1}\right)$ & $116.65 \pm 2.62$ & $255.30 \pm 1.45$ \\
\hline Reducing sugars $\left(\mathrm{g} \mathrm{gmolasses}^{-1}\right)$ & $11.65 \pm 0.26$ & $76.60 \pm 0.44$ \\
\hline Glucose $\left(\mathrm{g} \mathrm{L}^{-1}\right)$ & $46.01 \pm 0.74$ & $145.23 \pm 1.49$ \\
\hline Fructose $\left(\mathrm{g} \mathrm{L}^{-1}\right)$ & $43.83 \pm 0.53$ & $136.87 \pm 8.05$ \\
\hline Total proteins $\left(\mathrm{mg} \mathrm{L}^{-1}\right)$ & $1.16 \pm 0.02$ & $\mathrm{ND}$ \\
\hline
\end{tabular}

$\mathrm{ND}=$ Not determinate

\subsection{Rhodotorula mucilaginosa ССТ3892 growth in sugarcane molasses}

As shown in Figure 1, the SC cultivation achieved the greatest microbial cell concentration $\left(16.42 \pm 0.32 \mathrm{~g} \mathrm{~L}^{-1}\right)$ compared to MYEC $\left(8.28 \pm 0.03 \mathrm{~g} \mathrm{~L}^{-1}\right)$ and MC $\left(7.15 \pm 0.29 \mathrm{~g} \mathrm{~L}^{-1}\right)$. This result was already expected and matches with Maldonade et al. (2012) results, since the authors concluded, through an experimental design, that the $\mathrm{MgSO}_{4} .7 \mathrm{H}_{2} \mathrm{O}$ and $\mathrm{KH}_{2} \mathrm{PO}_{4}$ concentrations are determining variables for the Rhodotorula mucilaginosa growth. In the MYEC and MC cultivations any of both nutrients were added.

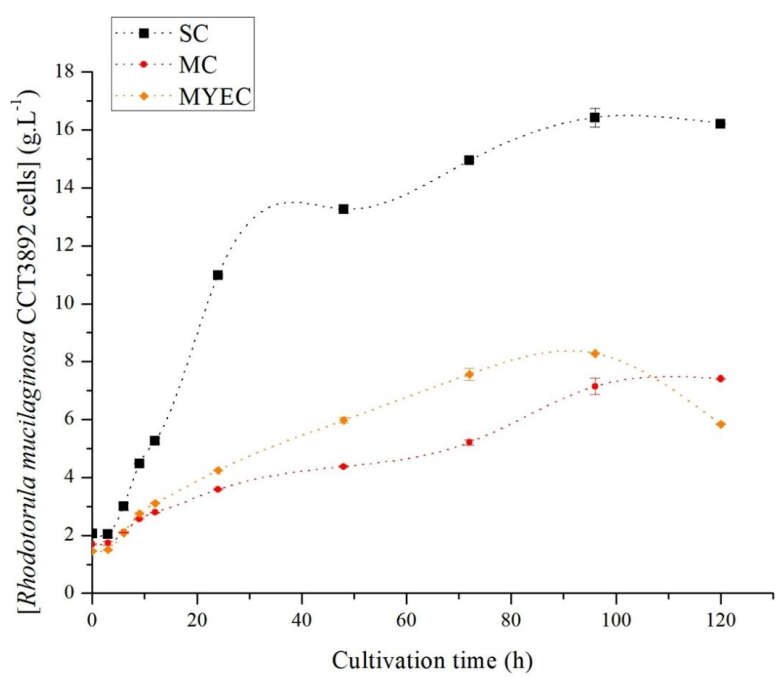

Figure 1. Rhodotorula mucilaginosa CCT3892 growth profiles obtained from the different cultivation conditions. Note: $\mathrm{SC}=$ synthetic medium; $\mathrm{MC}=$ molasses medium; and $\mathrm{MYEC}=$ molasses medium added yeast extract.

About the same topic, Lian et al. (2013) made an evaluation about the use of non-hydrolysate levoglucosans as carbon source for the Rhodotorula glutinis growth and obtained, from their best condition, a microbial cell concentration of $6.8 \mathrm{~g} \mathrm{~L}^{-1}$, what is really close to the obtained from the MC condition. Silva et al. (2018), using the same strain as the present research, obtained $6.95 \mathrm{~g} \mathrm{~L}^{-1}$ of dry cells in a process 
using a cassava wastewater dilution $\left(70 \% \mathrm{v} \mathrm{v}^{-1}\right)$ as main substrate, reinforcing that the carbon source is a key parameter for this singular bioprocess.

Also through an experimental design, Banzatto et al. (2013) obtained an optimum dry biomass concentration (14.87 $\left.\mathrm{g} \mathrm{L}^{-1}\right)$ using sugarcane molasses supplemented with a commercial nutrient named Nitrofosfo KL. The same behavior in relation to the presence of a nitrogen source was observed between the MYEC and MC cultivations, where a yeast extract supplementation $\left(3.0 \mathrm{~g} \mathrm{~L}^{-1}\right)$ increased the microbial biomass content by $15.80 \%$.

About the substrate consumption (Figure 2), and its conversion to microbial biomass (Figure 3), it was verified that $\mathrm{SC}$ cultivation presented the higher conversion factor $\left(0.512 \pm 0.15 \mathrm{~g} \mathrm{~g}^{-1}\right)$ compared to $\mathrm{MC}$ $\left(0.234 \pm 0.019 \mathrm{~g} \mathrm{~g}^{-1}\right)$ and MYEC $\left(0.232 \pm 0.002 \mathrm{~g} \mathrm{~g}^{-1}\right)$. These results indicate that a higher glucose presence in the cultivation medium induces the yeast metabolism to cell production instead of others metabolic activities. The experimental findings reported by Gong et al. (2019) confirm the same observation of this paper, since their results showed a cell concentration reduction of $31.48 \%$, for a Rhodotorula glutinis strain, when the carbon source was switched from glucose $\left(40 \mathrm{~g} \mathrm{~L}^{-1}\right)$ to fructose $\left(40 \mathrm{~g} \mathrm{~L}^{-1}\right)$.

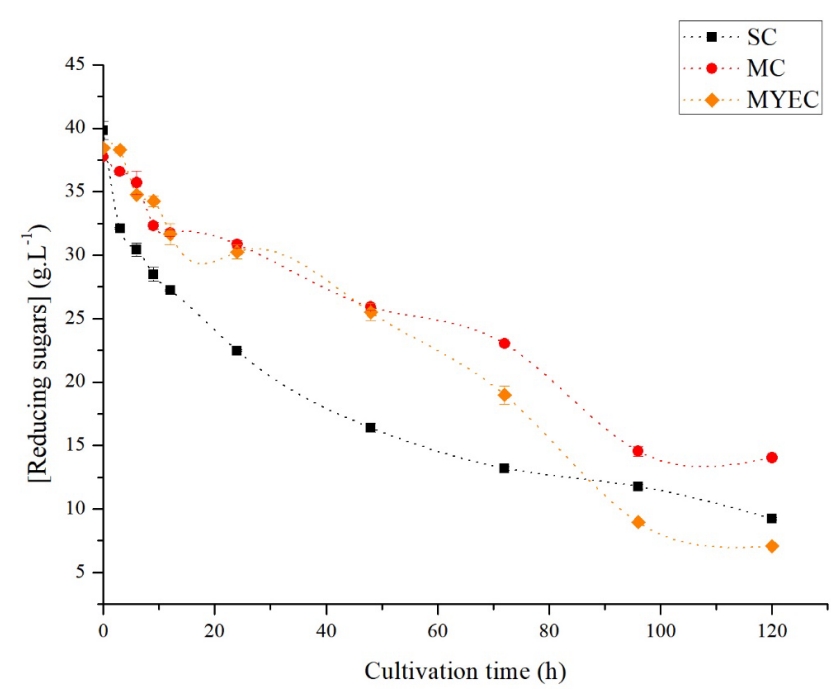

Figure 2. Rhodotorula mucilaginosa CСТ3892 reducing sugar consumption profiles obtained from the evaluated conditions. Note: $\mathrm{SC}=$ synthetic medium; $\mathrm{MC}=$ molasses medium; and $\mathrm{MYEC}=$ molasses medium added yeast extract.

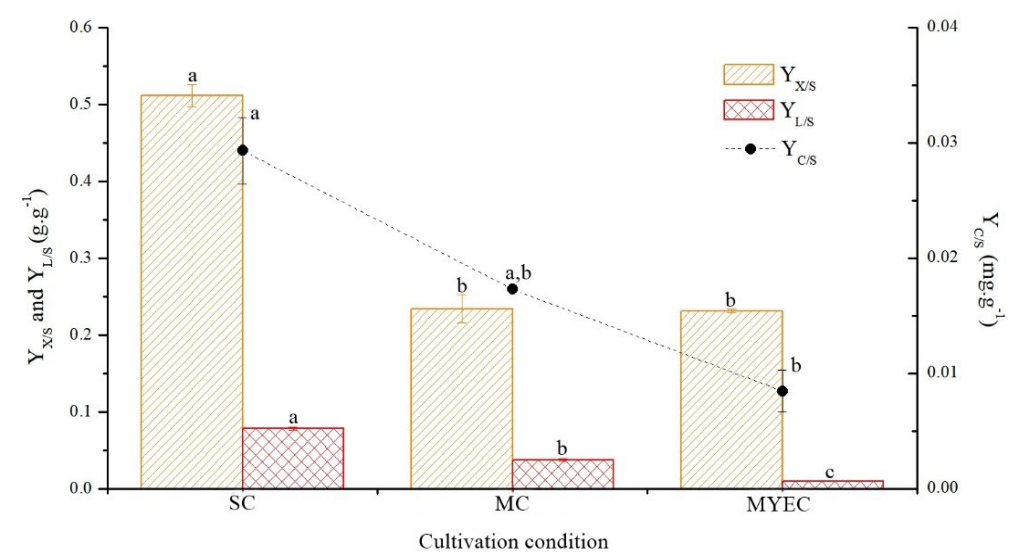

Figure 3. Stoichiometric parameters for the substrate conversion into cell $\left(\mathrm{Y}_{\mathrm{X} / \mathrm{S}}\right)$, lipids $\left(\mathrm{Y}_{\mathrm{L} / \mathrm{S}}\right)$ and carotenoids $\left(\mathrm{Y}_{\mathrm{C} / \mathrm{S}}\right)$. Different letter indicates different values at a 95\% of confidence level, $p<0.05$ (Tukey test). Note: $\mathrm{SC}=$ synthetic medium; $\mathrm{MC}=$ molasses medium; and $\mathrm{MYEC}=$ molasses medium added yeast extract. 


\subsection{Oil-lipids, carotenoids and fatty acids production}

The total lipids quantification (Figure 4) evidenced that both cultivations, SC and MC, presented the same oil-lipids percentage $(15.36 \% \pm 1.36 \%$ and $16.50 \% \pm 0.68 \%$, respectively). From this result, it is also possible to conclude that the reducing sugars consumption in $\mathrm{MC}$ was preferably destined for metabolites production than for cell growth.

In the MYEC, the yeast extract addition induced the other cellular activities instead of oil-compounds accumulation once the total lipids production obtained, $4.38 \% \pm 0.75 \%$, was nearly four times lower than in the other evaluated conditions.

Liu et al. (2015) showed that their best lipids percentage obtained was $36.4 \%$, from a Rhodotorula glutinis cultivation using corncob hydrolysate as carbon source at a carbon/nitrogen ratio $(\mathrm{C} / \mathrm{N})$ of 75 . This $\mathrm{C} / \mathrm{N}$ was six times larger than the used in this work and an exemplification of the $\mathrm{C} / \mathrm{N}$ effect may also be noticed in the behavior that occurred between the MC and MYEC, where the decrease in the $\mathrm{C} / \mathrm{N}$ induced to a mitigation in the total lipids accumulation. Besides that, Silva et al. (2018) obtained, using the same strain as this present study, a total lipids percentage of $13.33 \%$ using a cassava wastewater dilution $\left(50 \% \mathrm{v} \mathrm{v}^{-1}\right)$ as substrate.

Reyna-Martínez et al. (2015) reported that their best lipid accumulation was about $20 \%$ from a Rhotodotorula mucilaginosa cultivation at a $\mathrm{C} / \mathrm{N}$ of 12.5 , what is close to the results reported in this paper.

The carotenoids concentration achieved (Figure 4) in the SC $\left(0.051 \pm 0.005 \mathrm{mg} \mathrm{g}^{-1}\right)$ was also reached in MC cultivation $\left(0.053 \pm 0.001 \mathrm{mg} \mathrm{g}^{-1}\right)$, what means that sugarcane molasses presents a chemical composition able to produce further the oil-dyes by the yeast metabolism. The MYEC produced only $0.032 \pm 0.007 \mathrm{mg} \mathrm{g}^{-1}$, about $40 \%$ less than the MC yield.

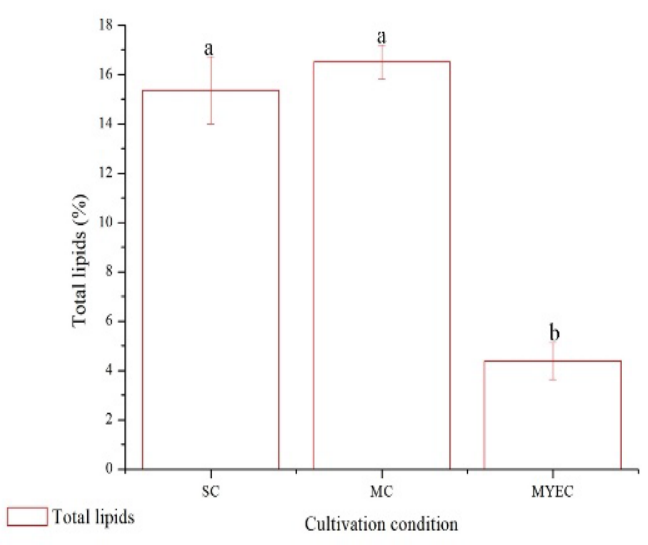

(a)

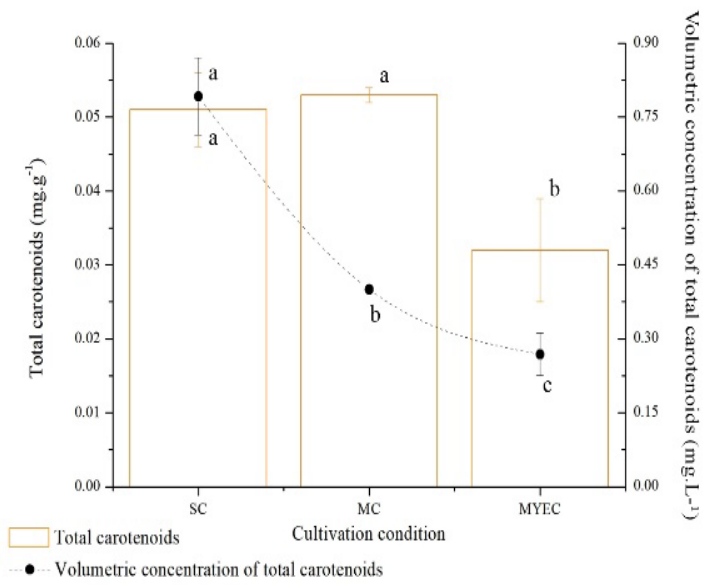

(b)

Figure 4. Total lipids (a), total carotenoids and volumetric concentration of total carotenoids (b) obtained from each cultivation condition. Different letter indicates different values at a $95 \%$ of confidence level, $p<0.05$ (Tukey test).

Note: $\mathrm{SC}=$ synthetic medium; $\mathrm{MC}=$ molasses medium; and $\mathrm{MYEC}=$ molasses medium added yeast extract.

The volumetric concentration of total carotenoids obtained from the MC cultivation was $0.400 \pm 0.001 \mathrm{mg} \mathrm{L}^{-1}$. This result is close to the obtained by Schneider et al. (2013), $0.6 \mathrm{mg} \mathrm{L}^{-1}$. The authors cultivated Rhodotorula glutinis using brewery effluent as main substrate and this comparison between both results reinforce the argument that sugarcane molasses is an applicable carbon source for this specific bioprocess. Figure 3 shows all the conversion factors of substrate into carotenoids $\left(\mathrm{Y}_{\mathrm{C} / \mathrm{S}}\right)$.

Based on the yeast kinetics behavior (Figure 5), it is easier to understand that the Rhodotorula metabolism presented different responses for each cultivation condition. In the SC, the yeast exponential phase of growth was between 3 and $24 \mathrm{~h}$ of process (Figure 1), in which we obtained a specific growth rate of $0.076 \pm 0.02 \mathrm{~h}^{-1}$ 
and a correlate generation time of $9.07 \pm 0.16 \mathrm{~h}$. However, the MC $\left(0.066 \pm 0.01 \mathrm{~h}^{-1}\right.$ and $\left.10.58 \pm 1.02 \mathrm{~h}\right)$ and MYEC $\left(0.10 \pm 0.00 \mathrm{~h}^{-1}\right.$ and $\left.6.91 \pm 0.04 \mathrm{~h}\right)$ presented the same phase between 3 and $9 \mathrm{~h}$ of cultivation, which denotes that, in both alternative conditions, the cells took little advantage of the substrate for cellular reproduction and directly passed to the stationary phase, where secondary metabolites are preferably produced.

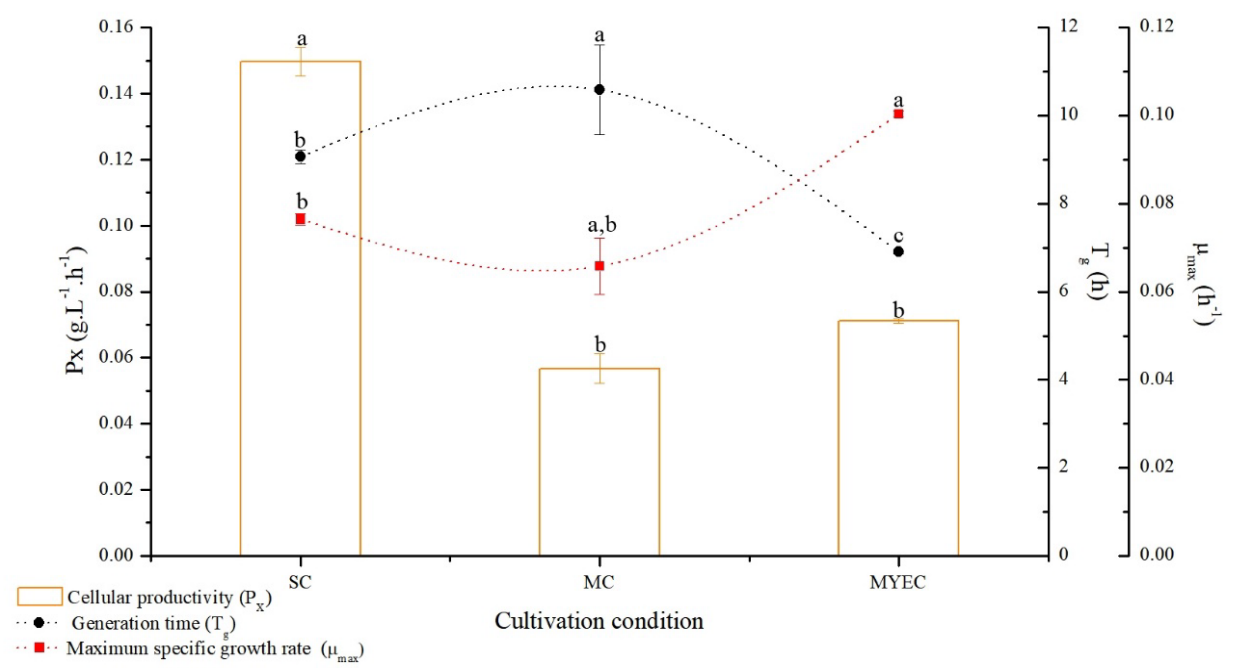

Figure 5. Results obtained for the cellular productivity $\left(\mathrm{P}_{\mathrm{x}}\right)$, maximum specific growth rate $\left(\mu_{\max }\right)$ and generation time $\left(\mathrm{T}_{\mathrm{g}}\right)$ from the different evaluated conditions. Different letter indicates different values at a $95 \%$ of confidence level, $p<0.05$ (Tukey test). Note: $\mathrm{SC}=$ synthetic medium; $\mathrm{MC}=$ molasses medium; and $\mathrm{MYEC}=$ molasses medium added yeast extract.

About the different growth behaviors noticed in the experimental results, it is possible to reinforce that the $\mathrm{SC}$ was favorable to the yeast reproduction once the cellular productivity achieved in this cultivation $\left(0.15 \pm 0.01 \mathrm{~g} \mathrm{~L}^{-1} \mathrm{~h}^{-1}\right)$ was statistically higher than the observed in the MC $\left(0.057 \pm 0.01 \mathrm{~g} \mathrm{~L}^{-1} \mathrm{~h}^{-1}\right)$ and MYEC $\left(0.071 \pm 0.00 \mathrm{~g} \mathrm{~L}^{-1} \mathrm{~h}^{-1}\right)$.

The fatty acids analysis (Table 2 ) reported that MC cultivation presented the most interesting profile once its majority product obtained was the oleic acid (74.05\%), followed by margaric acid (11.54\%) and stearic acid (9.64\%). This result confirms the sugarcane molasses as a remarkable carbon source for this bioprocess, since its application mainly improves the production of unsaturated fatty acids, which are one of the most important nutritional compounds for human supply (Vannice \& Rasmussen, 2014).

Table 2. Fatty acids profile for each cultivation condition.

\begin{tabular}{cccc}
\hline Fatty acid & SC (\%) & MC (\%) & MYEC (\%) \\
\hline Capric acid (C10:0) & 3.07 & - & - \\
\hline Stearic acid (C18:0) & 16.19 & 9.64 & - \\
\hline Lauric acid (C12:0) & 6.47 & 0.67 & - \\
\hline Linolenic acid (C18:2n6c) & 17.82 & 3.17 & - \\
\hline$\alpha$-Linolenic acid (C18:3n3) & 19.37 & 0.93 & 17.83 \\
\hline Myristic acid (C14:0) & 8.61 & 11.54 & 12.89 \\
\hline Margaric acid (C17:0) & - & 74.05 & 39.54 \\
\hline Oleic acid (C18:1n9c) & 16.66 & - & 11.81 \\
\hline Palmitic acid (C16:0) & 11.81 & - & 9.32 \\
\hline Pentadecanoic acid (C15:0) & - & 100 & 100 \\
\hline Total & 100 & & \\
\hline
\end{tabular}

Note: $\mathrm{SC}=$ synthetic medium; $\mathrm{MC}=$ molasses medium; and $\mathrm{MYEC}=$ molasses medium added yeast extract. 
Khot \& Ghosh (2017) studied Rhodotorula mucilaginosa IIPL32 oil-lipids production and obtained, from their best condition, an oleic acid amount of $40.41 \%$, using sugarcane bagasse at a xylose concentration of $40 \mathrm{~g} \mathrm{~L}^{-1}$. Gientka et al. (2017) also obtained a predominant oleic acid production by Rhodotorula mucilaginosa and their best yield was $36.6 \%$, which is lower than the result found in this study.

\section{Conclusions}

According to the prominent results presented in this paper, it is possible to conclude that the Rhodotorula mucilaginosa CCT3892 cultivation in sugarcane molasses is a great alternative for the oil-lipids, carotenoids and fatty acids bioproduction. The predominance of unsaturated fatty acids in the MC profile indicates that this bioprocess condition is an interesting pathway for obtaining oil-compounds. The $\mathrm{C} / \mathrm{N}$ needs to be optimized to improve the yields and future studies will be conducted from this perspective.

\section{Acknowledgements}

The authors thank CNPq and CAPES for the financial supporting, the Japunguu Agroindustrial group for the sugarcane molassessupply and the André Tosselo Foundation for the microorganism donation.

\section{References}

Banzatto, D., Freita, L. A., \& Mutton, M. J. R. (2013). Carotenoid production by Rhodotorula rubra cultivated in sugar cane juice, molasses and syrup. Science and Food Technology, 33, 14-18. http://dx.doi.org/10.1590/S0101-20612013000500003

Bradford, M. M. (1976). A rapid and sensitive method for the quantitation of microgram quantities of protein utilizing the principle of protein-dye biding. Analytical Biochemistry, 72(1-2), 248-254. PMid:942051. http://dx.doi.org/10.1016/0003-2697(76)90527-3

Cardoso, L. A. C., Jäckel, S., Karp, S. G., Framboisier, X., Chevalot, I., \& Marc, I. (2016). Improvement of Sporobolomyces ruberrimus carotenoids production by the use of raw glycerol. Bioresource Technology, 200, 374-379. PMid:26512861. http://dx.doi.org/10.1016/j.biortech.2015.09.108

Cheng, Y., \& Yang, C.-F. (2016). Using strains Rhodotorula mucilaginosa to produce carotenoids using food wastes. Journal of the Taiwan Institute of Chemical Engineers, 16, 270-275. http://dx.doi.org/10.1016/j.jtice.2015.12.027

Colet, R., Di Luccio, M., \& Valduga, E. (2015). Fed-Batch production of carotenoids by Sporidiobolus salmonicolor (CBS 2636): Kinetic and stoichiometric parameters. European Food Research and Technology, 240(1), 173-182. http://dx.doi.org/10.1007/s00217-014-2318-5

Frengova, G., Simova, E., Pavlova, K., Beshkova, B., \& Grigorova, D. (1994). Formation of carotenoids by Rhodotorula glutinis in whey ultrafiltrate. Biotechnology and Bioengineering, 44(8), 888-894. PMid:18618906. http://dx.doi.org/10.1002/bit.260440804

Garay, L. A., Boundy-Mills, K. L., \& German, J. B. (2014). Acumulation of high value lipids in single cell microorganisms. Journal of Agricultural and Food Chemistry, 62(13), 2709-2727. PMid:24628496. http://dx.doi.org/10.1021/jf4042134

Gientka, I., Gadaszewska, M., Błażejak, S., Kieliszek, M., Bzducha-Wróbel, A., Stasiak-Różańska, L., \& Kot, A. M. (2017). Evaluation of total lipids biosynthesis ability by Rhodotorula and Sporobolomyces strains in medium with glycerol. European Food Research and Technology, 243(2), 275-286. http://dx.doi.org/10.1007/s00217-016-2742-9

Gong, G., Liu, L., Zhang, X., \& Tan, T. (2019). Comparative Evaluation of different carbon source supply on simultaneous production of lipid and carotene of Rhodotorula glutinis with irradiation and the assessment of key gene transcription. Bioresource Technology, 288, 121559. PMid:31152958. http://dx.doi.org/10.1016/j.biortech.2019.121559

International Union of Pure and Applied Chemistry - IUPAC. (1987). Standard methods for the analysis of oils fats and derivatives (6th ed.). Venice: IUPAC.

Kanzy, H. M., Nasr, N. F., El-Shazly, H. A. M., \& Barakata, O. S. (2015). Optimization of carotenoids production by yeast strains of Rhodotorula using Salted Cheese. International Journal of Current Microbiology and Applied Sciences, 4, 456-469.

Khot, M., \& Ghosh, D. (2017). Lipids of Rhodotorula mucilaginosa IIPL32 with biodiesel potential: Oil yield, fatty acid profile, fuel proprieties. Journal of Basic Microbiology, 57(4), 345-352. PMid:28155998. http://dx.doi.org/10.1002/jobm.201600618

Lian, J., Garcia-Perez, M., \& Chen, S. (2013). Fermentation of levoglucosan with oleaginous yeast for lipid production. Bioresource Technology, 133, 183-189. PMid:23425586. http://dx.doi.org/10.1016/j.biortech.2013.01.031

Lima, C. S. S., Conceição, M. M., Silva, F. L. H., Lima, E. E., Conrado, L. S., \& Leão, D. A. S. (2013). Characterization of acid hydrolysis of sisal. Applied Energy, 102, 254-259. http://dx.doi.org/10.1016/j.apenergy.2012.09.061

Liu, Y., Wang, Y., Liu, H., \& Zhang, J. (2015). Enhanced lipid production with undetoxified corncob hydrolysate by Rhodotorula glutinis using high density culture strategy. Bioresource Technology, 180, 32-39. PMid:25585258. http://dx.doi.org/10.1016/j.biortech.2014.12.093 
Maldonade, I. R., Rodriguez-Amaya, D. B., \& Scamparini, A. R. P. (2012). Statistical optimization of cell growth and carotenoid production by Rhodotorula mucilaginosa. Brazilian Journal of Microbiology, 43(1), 109-115. PMid:24031809. http://dx.doi.org/10.1590/S1517-83822012000100012

Manirakiza, P., Covaci, A., \& Schepens, P. (2001). Comparative study on total lipid determination using Soxhlet, Roese-Gottlieb, Bligh \& Dyer, and modified Bligh \& Dyer extraction methods. Journal of Food Composition and Analysis, 14(1), 93-100. http://dx.doi.org/10.1006/jfca.2000.0972

Mata-Gómez, L., Montañez, J., Méndez-Zavala, A., \& Aguilar, C. (2014). Biotechnological production of carotenoids by yeasts: An overview. Microbial Cell Factories, 13(1), 12. http://dx.doi.org/10.1186/1475-2859-13-12

Mesquita, S. S., Teixeira, C. M. L. L., \& Servulo, E. F. C. (2017). Carotenóides: Propriedades, aplicações e mercado. Revista Virtual de Química, 9(2), 672-688.

Miller, G. L. (1959). Use of dinitrosalicylic reagent for determination of reducing sugar. Analytical Chemistry, 31(3), $426-428$. http://dx.doi.org/10.1021/ac60147a030

Mouat, M. J., \& Prince, R. (2018). Cultured meat and cowless milk: On making markets for animal-free food. Journal of Cultural Economics, 11(4), 315-329. http://dx.doi.org/10.1080/17530350.2018.1452277

Nelson, D. L., \& Cox, M. M. (2014). Estrutura e catálise: Lipídios. In D. L. Nelson \& M. M. Cox, Princípios de bioquímica de Lehninger (Cap. 10, pp. 357-385). Porto Alegre: Artmed.

Reyna-Martínez, R., Gomez-Flores, R., López-Chuken, U. J., González-González, R., Fernández-Delgadillo, S., \& BalderasRentería, I. (2015). Lipid production by pure and mixed cultures production by pure and mixed cultures of Chlorella pyrenoidosa and Rhodotorula mucilaginosa isolated in Nuevo Leon, Mexico. Applied Biochemistry and Biotechnology, 175(1), 354-359. PMid:25274117. http://dx.doi.org/10.1007/s12010-014-1275-6

Ribeiro, J. E. S., et al (2017). Preliminary investigation of reuse of Ricotta-cheese whey (scotta) as substrate for the growth of Rhodotorula glutinis intended for the production of carotenoids. Journal of Agricultural and Biological Science, 12(10), 302-306.

Schneider, T., Graeff-Hönninger, S., French, W. T., Hernandez, R., Merkt, N., Claupein, W., Hetrick, M., \& Pham, P. (2013). Lipid and carotenoid production by oleaginous yeast Rhodotorula glutinis cultivated on brewery effluents. Energy, 61, 34-43. http://dx.doi.org/10.1016/j.energy.2012.12.026

Silva, J., Silva, F. L. H., Santos, S. F. M., Ribeiro, J. E. S., Medeiros, L. L., \& Ferreira, A. L. O. (2018). Biomass and lipid production by yeast Rhodotorula mucilaginosa using cassava wastewater as the substrate. Brazilian Journal of Food Technology, 21, e2017145.

Vannice, G., \& Rasmussen, H. (2014). Position of the academy of Nutrition and Dietetics: Dietery fatty acid for heath adults. Journal of the Academy of Nutrition and Dietetics, 114(1), 136-153. PMid:24342605. http://dx.doi.org/10.1016/j.jand.2013.11.001

Voet, D., \& Voet, J. G. (2013). Biomoléculas: Lipídeos e membranas. In D. Voet \& J. G. Voet, Bioquímica (Cap. 12, pp. 386449). Porto Alegre: Artmed.

Zenebon, O., Sadocco, N., \& Tiglea, P. (2008). Physical-chemical methods for food analysis (1st ed.). São Paulo: Aldolf Lutz Institute. 